\title{
Trickster Defeats the Revolution: Egypt as the Vanguard of the New Authoritarianism
}

\author{
WALTER ARMBRUST \\ Oxford University, UK
}

\begin{abstract}
Egypt's January 25 Revolution often has been viewed as an explicit contest between the Hosni Mubarak regime and its cronies, who were able to prevail by pulling the levers of a "deep state," and revolutionaries espousing progressive visions, albeit visions divided between those of Islamists and non-Islamists, and often seen by each as mutually incompatible with the other. The defeat of the January 25 Revolution's progressive aspirations can be understood, to a substantial degree, as a victory by the old regime. However, revolution understood as a Liminal Crisis allows us to see the rise of 'Abd alFattah al-Sisi not as a straightforward restoration of the old regime, but as both a revolutionary outcome and as an instantiation of a New Authoritarianism that has been making significant strides toward power in the wake of the 2011 revolutions. Liminality is understood here as the intermediate stage in a transition as described in Victor Turner's Ritual Process and recently reinterpreted in the context of politics by Bjørn Thomassen. The potential dangers of liminality often are controlled by ritual, but this is not the case in revolutions, which become liminal crises precisely because there is no conventionalized means for closing off the state of being in-between. In such circumstances Tricksters-beings at home in liminality and often-elaborated in myth, folklore, and literature-become potentially dangerous in politics. Sisi can be seen as a Trickster politician. But more broadly, the structuring of liminality through the global political-economic order of contemporary capitalism both creates a generalized precarity outside the most elite levels of society, and at the same time predisposes those compelled to live in precarity to be attentive to political Tricksters. Hence liminality can be seen as both the beginning and the end of revolution
\end{abstract}

Key Words: Authoritarianism; Egypt; January 25 Revolution; Liminality; Mohamed Morsi; 'Abd al-Fattah al-Sisi; Trickster; Donald Trump

The distinction between failure and defeat in a revolution is significant. Failure puts the onus for disaster on those who dared to revolt. Defeat shifts the analytical lens toward a different agent - the political work that went into making a reversal of the revolutionaries' goals appear inevitable. My point of departure is that the Egyptian “counter-revolution,” was a coherent movement before 'Abd al-Fattah al-Sisi overthrew Mohamed Morsi in a coup, and not simply a resurgence of the old Mubarak regime. Secondly I examine the connection between the January 25 Revolution and the wave of authoritarianism sweeping across the world following the revolutionary moment in 2011. Have we misrecognized "counter- 
revolution” as a potential end of the January 25 Revolution? Was Sisi a revolutionary outcome, albeit not the one proponents of the revolution intended? How is the rolling back of Egypt’s revolution connected to broader global political-economic structures?

It is difficult to exaggerate how different the world felt six years after the outbreak of the January 25 Revolution. When the Arab revolutions of 2011 happened, they appeared to be connected to broader currents of unrest that had been percolating for some time. In the United States the Occupy Movement shook the capitalist consensus that gnawed at the roots of democracy. A number of comparable European movements emerged starting in the mid2000s. The Green Movement in Iran unsettled the conservative foundations of an Islamic state. Leftist politicians were winning elections in many South American countries throughout the 2000s.

Fast-forward to 2016. Almost all of the promising progressive movements and political parties from the early 2000s lay in ruins. Donald Trump was elected as President of the United States. It is an understatement to say that nobody foresaw the rise of an almost openly fascist American politician in 2011, or more generally, the coalescence of a new international authoritarianism. Contrary to conventional expectations that peripheral nations react to events in the metropole, Egypt was ahead of the curve in the global emergence of the new authoritarianism. I will elaborate on this below. First I want to go back to the first glimmerings of what some have called “Trickster politics” ${ }^{1}$ in the January 25 Revolution. Sisi and Trump are both Trickster Politicians. Sisi’s emergence as Egypt's ruler took place in a revolutionary context that was conducive to Trickster politics, and I argue that Sisi was himself more of a Trickster than one might think at first glance. Moreover, Sisi had a

\footnotetext{
Correspondence address: Walter Armbrust, St. Antony’s College, Oxford OX2 6JF, United Kingdom. Email: walter.armbrust@sant.ox.ac.uk

${ }^{1}$ Forename Forlenza \& Bjørn Thomassen (2016) Title ......
} 
predecessor, one who was not exactly a protégé, but who was clearly connected to him, and who blazed a trail that the eventual ruler followed.

\section{The Warm-Up Act}

The decisive months in the Revolution were from October 2011 to February 2012, a period of massacres and street battles. First came the Maspero Massacre of mostly Coptic protestors in October, the subtext of which was to bury any attempts to forge cross-confessional prorevolutionary alliances in an avalanche of sectarianism. Then in November the Battle of Mohamed Mahmud Street, sparked by tensions in the wake of the Supreme Council for the Armed Forces (SCAF’s) machinations to guarantee itself freedom from civilian oversight in whatever political order was to emerge. Next, in December, the violent breakup of a sit-in at the Ministerial Council formed in protest of the interim government's actions in the Mohamed Mahmud crisis. Finally on February 2, 2012 (the anniversary of the fall of the Mubarak regime) a massacre in Port Said of 74 members of a football fan club that had played a prominent role fighting the security forces in the early days of the Revolution; and after the massacre, another long-running battle of attrition against the security forces. ${ }^{2}$ At the

\footnotetext{
${ }^{2}$ On Maspero see Sarah Carr (2011) 'A Firsthand Account: Marching from Shubra to Deaths at Maspero,' Egypt Independent, October 10, 2011. Available online at: http://www.egyptindependent.com/news/firsthandaccount-marching-shubra-deaths-maspero, accessed on January 24, 2016; and Momen El Husseini (2011) The 'Maspero Crime': Accounts against the Counter-Revolution's Power, Media, and Religion, Jadaliyya, October 31, 2011. Available online at: http://www.jadaliyya.com/pages/index/3022/the-maspero-crime accountsagainst-the-counter-rev, accessed on January 24, 2016. For a perceptive account of the dynamics of the Battle of Muhammad Mahmud Street, see Lucie Ryzova (2011) 'Teargas, Hairgel and Tramadol: The Battle of Muhammad Mahmud Street,' in Jadaliyya, November 28, 2011. Available online at: http://www.jadaliyya.com/pages/index/3312/the-battle-of-muhammad-mahmud-street_teargas-hair-, accessed on August 12, 2016. The Maglis al-Wuzara' violence tends to be either assimilated to Muhammad Mahmud, obscured by coverage and commentary of the then-onrushing parliamentary elections, or associated with one particularly shocking image of uniformed soldiers viciously attacking a woman. See 'Al-Fidyu alKamil li-Intihakat al-Gaysh fi Maglis al-Wuzara' (2011) Available online at: https://www.youtube.com/watch?v=KjHO3CjBsgs, accessed on December 21, 2016. On the Port Said Massacre, its aftermath, and the role of the Ultras' football fan clubs in politics, the best analysis by far can be found in Carl Rommel (2015) 'Revolution, Play and Feeling: Assembling Emotionality, National Subjectivity and Football in Cairo, 1990-2013', PhD Thesis, University of London, School of Oriental and African Studies.
} 
beginning of October most of the revolutionary political spectrum was chanting "down with military rule” at demonstrations. Politically less-engaged members of a broad middle class looked on, unsure whether or not to side with the military rulers or the revolution. By February 2012 the country had experienced a sea change. The "sectarian card” had been played with a vengeance by the government and exploited by Islamists. The Supreme Council for the Armed Forces, by the end of 2011, had little choice but to hand over power to a civilian government. A long-suspected political bargain between SCAF and the Muslim Brotherhood was, by February 2012, a fait accompli.

Through most of the first two years of the Revolution I was on research leave, and living in Cairo while conducting research on the history of Egyptian mass media. The Revolution was a constant presence just outside my front door, hence I could not have ignored it even if I had wanted to do so. The most interesting event I observed during that period was an anti-revolution rally in 'Abbasiyya Square near the Ministry of Defence. ${ }^{3}$ It happened on December 23, 2011, not long after the violent break-up of the Ministerial Council sit-in protesting the appointment of Kamal al-Ganzuri as Prime Minister. Ganzuri, a Mubarak-era dinosaur known for his harsh security policies, was appointed as implicit punishment for the previous month’s six-day battle on Mohamed Mahmud Street. During the breakup of the Ministerial Council sit-in, a shocking video emerged of a woman beaten to the ground by soldiers in army uniforms. Revolutionary forces called for a large demonstration in Tahrir, dubbed “The Friday of Regaining Honour” (gum 'at radd al-i 'tibar) on December 23. Several thousands attended that demonstration.

The parallel 'Abbasiyya counter-demonstration, on the same day, was called "The Friday of the Crossing” (gum 'at al- 'ubur) in honour of the crossing of the Bar Lev Line in the 1973 October War — the finest hour of the Egyptian armed forces. Only a few hundred

\footnotetext{
${ }^{3}$ Armbrust (2013) provide citation......
} 
people came, most of them security or military forces in plain clothes. The atmosphere was menacing. Banners called for the execution of pro-Revolution media figures. Tough-looking men held signs condemning the revolution or praising the army and the police. Reporters from unsympathetic organizations were roughed up. I edged out of the crowd and left when some of the attendees started asking if I was a journalist.

The person credited with organizing the Friday of the Crossing was a bombastic television talk show host, Taufiq 'Ukasha. He initially struck most observers as ridiculous, and he mercilessly was mocked by the pro-revolution camp. Ramy 'Isam, a revolutionary singer beloved among leftist revolutionaries, was in Tahrir Square that day singing "Ya 'Uksha”- - derogatory diminutive the name 'Ukasha—to a gleeful audience. "Move your meaty face on the screen, and cut the crap, ya 'Uksha.” 'Isam belittled 'Ukashas's manhood and made him a laughing stock. "What drug are you on ya 'Uksha? Your bloat fills the screen and your double chin needs a porter."4

'Ukasha made his own appearance that day a few kilometres away in Midan 'Abbasiyya, but his real home was television, where he spun wild conspiracy theories about plots against Egypt by immense collectives of enemies: Freemasons, the Revolutionary Socialists, Qatar, the United States, world Jewry, the April $6^{\text {th }}$ movement, Hamas, the Kefaya movement, Google, the Muslim Brotherhood (but not the Salafis), NATO, Hizballah, Israel and Iran. 'Ukasha’s blatantly populist register was vulgar to the point of absurdity, and apparently ignorant. At one point he famously warned of a Masonic conspiracy that would unfold on " $13 / 13 / 13$ " — the thirteenth day of the thirteenth month of $2013 .{ }^{5}$

\footnotetext{
${ }^{4}$ Rami 'Isam (2011) Ughniyya Ya 'Uksha Ihda' li-Taufiq 'Ukasha min Midan al-Tahrir. Available online at https://www.youtube.com/watch?v=4aIFMviAUuc, accessed on August 2, 2016.

${ }^{5}$ Taufiq 'Ukasha Yahdhar min 13/13/13 (2011). Available online at

https://www.youtube.com/watch?v=8YfVtNxMzT0 accessed on 7 January, 2017.
} 
'Ukasha was adamant about the dangers posed to Egypt by the Muslim Brotherhood, and slavishly devoted to the military precisely when the most vocal calls were being made for its downfall. Many observers thought he was flat-out an operative of military intelligence, at the time headed by 'Abd al-Fattah al-Sisi. After Mohamed Morsi was elected, 'Ukasha helped to plant the notion that Sisi was a crypto-Muslim Brother. On the day of Sisi's appointment as Minister of Defense, 'Ukasha appeared on the air in ostensibly his last appearance before the government banned him, warning the public to beware of the Muslim Brotherhood's “man in the armed forces":

I will hold the Muslim Brotherhood in particular responsible for my security, and responsible for closing the Fara'ayn Channel. That's first. Second, I hold the Military Council responsible for my security, from Field Marshall Muhammad Husayn al-Tantawi down to the last member of the Military Council, who is General 'Abd al-Fattah al-Sisi, the Director of Military Intelligence, and the Muslim Brotherhood's man in the armed forces. ${ }^{6}$

But Sisi’s drama with Mohamed Morsi came later. When I attended the ‘Abbasiyya demonstration at the end of 2011, thousands of people across the country were demonstrating against the military, as opposed to the few hundreds at 'Ukasha's rally. Yet clearly, in hindsight, the small demonstration in 'Abbasiyya was a far better barometer of Egypt's political trajectory than the much larger one in Tahrir Square. How, then, should we assess the significance of 'Ukasha for Egyptian politics? Beyond 'Ukasha’s local significance, can we link Egyptian politics to larger political structures that shape the international political context that we live in today?

\section{Creatures of Liminality}

\footnotetext{
6 ‘Ukasha Yatanaba’u bi-Tai‘yin ‘Abd al-Fattah al-Sisi Ragil al-Ikhwan fi al-Gaysh (2012). Available online at https://www.youtube.com/watch?v=CYrJRWveQTw, accessed on August 2, 2016.
} 
'Ukasha exemplifies a political Trickster, and has been compared with American media

figures such as Rush Limbaugh and Glenn Beck, who are political talk show hosts and not

politicians. ${ }^{7}$ But comparisons between 'Ukasha and Limbaugh or Beck were made before the rise to political prominence of a reality television host named Donald Trump, whom I could not help thinking of as the American 'Ukasha.

The rise of Trump often is associated with a phenomenon that has been labelled PostTruth Politics. I want to translate Post-Truth Politics to a different form, which we can call “Trickster politics.” The term “trickster” rarely has been invoked in the context of politics. Tricksters are normally figures one encounters in studies of mythology, folklore, anthropology, or literary studies. The potential to be both creative and destructive lies at the heart of the Trickster, who is exquisitely ambivalent: potentially powerful, ridiculous, and dangerous. ${ }^{8}$ The term designates both a character and a type of narrative found across all modern cultures and in antiquity. The Greek God Dionysus is a Trickster figure, as is Hermes. Anansi, a west African spider-shaped folk character, is a trickster. Juha and

\footnotetext{
${ }^{7}$ The circumstances of the comparison are a tangled tale that leads partly to me. In one of his broadcasts Ukasha attempted to interpret the comparison with Beck as validation of his own importance. This came after he had been elected to a slavishly pro-Sisi parliament. The program focused on the international attention he had received, in an effort to transform his public persona in Egypt into that of a serious politician, and thereby support his openly declared ambition to become Speaker of the parliament: Al-Halqa al-Kamila li-Birnamig 'Masr al-Yaum' (2015), December 12, 2015. Available online at https://www.youtube.com/watch?v=3f_RgE3cU44, accessed on December 19, 2016. Much of the program was devoted to discussing a newspaper article on him written by Hisham Barakat, the editor-in-chief of the newspaper al-Mugaz: Hisham Barakat (2015) Hisham Barakat Yaktub ‘an Taufiq 'Ukasha, The Glenn Beck [of] Masr, Al-Mugaz, December 9, 2015. Available online at http://www.elmogaz.com/node/244630, accessed on December 19, 2016. Barakat's article was heavily based on an Arabic translation of my own article on 'Ukasha; seeWalter Armbrust (2013) 'The Trickster in the January 25 Revolution, Comparative Studies in Society and History 55 (4); inclusive page numbers?; and the translation (published as a small book): Walter Armbrust (2015) Hawi al-Thaura al-Misriyya: Dirasa Antrubulujiyya li-Zahirat Taufiq 'Ukasha (Riyad, Kingdom of Saudi Arabia: Markaz Nama'). In an earlier broadcast he had dismissed the publication on grounds that the translator was allegedly a member of the Muslim Brotherhood: 'Ukasha fi Aqwa Ta'liq 'ala Kitab Hawi alThaura (2015). Available online at https://www.youtube.com/watch?v=Ks14_d9Lb8E, accessed on 7 January, 2017. It is hard to tell whether or not 'Ukasha's reputational campaign at the end of 2015 succeeded in getting the Egyptian public to take him seriously as a conventional politician. By March 2016 his membership in the Parliament was revoked on a number of grounds, including unauthorized normalization with Israel, after he had invited the Israeli ambassador to dinner: Asbab Isqat 'Adawiyyat Taufiq 'Ukasha min al-Barliman (2016) AlBarlimani, March 2, 2016. Available online at http://tinyurl.com/jlbwqz8, accessed on December 19, 2016.

${ }^{8}$ Paul Radin (1956) The Trickster: A Study in American Indian Mythology; with a commentary by Karl Kerényi and Carl G. Jung (New York: Philosophical Library), p. ix.
} 
Nasreddin Hoja in the Middle East, and Pan, Puck, and Bre'r Rabbit are tricksters. In Norse mythology Loki is a trickster. Rumpelstiltskin, the Pink Panther, the Joker, Dr. Who and Bart Simpson also are tricksters.

While most scholarship on the phenomenon of the Trickster is cultural, Tricksters are highly relevant to politics. Bjørn Thomassen has been made this point most eloquently, arguing that the key to Trickster politics is liminality, the quality of being in-between, particularly in the context of transitions. A Trickster is a being at home in liminality-the wanderer who appears in a village and captivates its inhabitants with alluring stories. If a Trickster is a being at home in liminality, then what exactly is liminality? It can be seen through what anthropologists have called "the ritual process," which is relevant to revolution, but also something increasingly "permanentized” in a socially corrosive manner. Before I discuss structured liminality I want first to discuss revolution through the ritual process. This is important, as the term "ritual" can be somewhat deceptive. Ritual is, among many other things, a means for trying to control the unpredictability of transitions. ${ }^{9}$ A classic case is "rites of passage," as described in a classic work by Arnold van Gennep in the early twentieth century. His insights were expanded by Victor Turner in the 1970s, and adapted to political theory recently by Thomassen. ${ }^{10}$ The ritual process involved breaking away from social

\footnotetext{
${ }^{9}$ There are many ways to approach ritual, and I make no pretence of summarizing them comprehensively. My focus here is on liminality, specifically in the context of major transformations. Liminality is also a property of ritual in the context of human action in general, and ritualization certainly can be employed to produce a sense of the mundane. Ritual practices, in other words, set certain practices off from general human activity, but are at the same time thoroughly intertwined with social constructions of order through "strategies of differentiation through formalization and periodicity, the centrality of the body, the orchestration of schemes by which the body defines an environment and is defined in turn by it, ritual. mastery, and the negotiation of power to define and appropriate the hegemonic order”: Catherine Bell (2009) Ritual Theory, Ritual Practice (Oxford: University of Oxford Press), p. 220. At a certain point the structuring capacity of ritualization may make even 'Abd alFattah al-Sisi mundane, or at least routinized. But such routinization was far from established at the beginning of 2017. Moreover, the structuring of liminality itself may mitigate against routinization (more on that below).

${ }^{10}$ Victor Turner (1977) The Ritual Process: Structure and Anti-Structure (Cornell: Cornell University Press); Bjørn Thomassen (2012) ‘Notes Toward an Anthropology of Political Revolutions', Comparative Studies in
} 
norms, and entry into a liminal phase in which normative social conventions are expected to be overturned. Initiates in the ritual were joined together in a state of solidarity that Turner termed "communitas," which we can understand intuitively as Tahrir Square during the mythical first 18 days of the Revolution. Finally, initiatites in the ritual process would be reincorporated into normative society in new social positions. This, of course, did not happen after the 18 days of Tahrir Square. Keep that point in mind, as I'll come back to it.

Before I return to communitas, it must be appreciated that ritual exists precisely because liminality is dangerous and, after the initial euphoria, uncomfortable-a point emphasized in Thomassen's re-framing of ritual theory for the analysis of politics. In liminality people are expected to do the unexpected. If possible there has to be some social mechanism for managing it. “The ritual process,” as Victor Turner called it, is both flexible and universal. It is flexible because the significance of a ritual can be adapted to social transitions generally; and universal in its simple but powerful form. It is also scalable. It can be as small as a handshake when you meet someone for the first time. It can take place on more collective stages. Rites of passage, for example, birth, death, marriage, coming of age, matriculation, graduation, are all rituals that transform one’s social state; one enters into a liminal phase, experiences communitas, does things one normally wouldn’t do; feels bonds with people one normally wouldn't feel bonded to, and then emerges transformed. But the ritual process, if not the ritual itself, also can apply to larger social scales. "Ritual” is a word we use to describe the way we manage the transitions we know will happen. But transitions happen that we can't predict, for example, natural disasters, wars, and revolutions. The meaning of such events can be illuminated productively through the concept of liminality, but the crucial point is that in the ritual process there is either a master of ceremonies or an accepted procedure for managing the dangers of liminality. In a revolution there is none. 
People enter into liminality from which there is no known exit, and hence no way back to whatever previously had constituted normality.

\section{The Trickster Triumphant}

To return to Egypt, the mythical 18 days of Tahrir Square were marked by communitas. Muslims prayed while the Christians stood and protected them. There was no sexual harassment. Class and regional differences that normally divide were erased. The mystique of Tahrir Square was buttressed by numerous retellings, and a vast amount of mass mediation. To be sure, many people mistrust the legend; there was no social levelling because people tended to group by social class or by regional origin; sexual harassment did take place; and the presence of the Muslim Brotherhood was highly annoying to non-Islamists from the outset. That may all be true, but the euphoria of the moment was nonetheless a social fact, without which the Revolution may not have been widely accepted as such. But while the transition from Mubarak necessarily plunged Egypt into a liminal state, experienced first as communitas, nobody knew what to do next. There was no "something else." What happens in this case?

Political theory focusing on the significance of liminality in politics is suggestive. What happens in a revolution can be thought of as a "liminal crisis" —a state of being stuck in liminality with no obvious way to get out of it. When that happens communitas fades; political forces begin to calculate their resources and take sides. In Egypt, as soon as communitas in Tahrir Square turned into memory, divisions between the Muslim Brotherhood and the non-Islamist political forces became obvious. The rest, as they say, is history—a long and complicated history, which I won't attempt to reiterate here. ${ }^{11}$

\footnotetext{
${ }^{11}$ I have, however, explored the dynamics between Islamists and non-Islamists (particularly Islamist discourses on Copts) in an on-going book on the Revolution. In this special issue, Schielke's contribution focuses specifically on the political and ethical dynamics between the Muslim Brotherhood and non-Islamist Egyptians.
} 
And so, with "liminality" firmly in mind, I want to return to the figure of the political Trickster. It is in a liminal crisis that the Trickster becomes a potentially dangerous model for leadership. The potentials of liminality, both creative and destructive, are at the heart of the Trickster, who is exquisitely ambivalent: potentially powerful, ridiculous, and dangerous. In modern politics Tricksters acquire a following when the conventional signposts of social and political life are thrown into doubt. Tricksters can be objects of ridicule, but in liminality ridicule can serve as affirmation, and outsiders can gather a following that normally would be unthinkable. In so doing, Tricksters can be seen as a solution to crisis, and therefore have a direct stake not in closing off liminality, but in perpetuating it. As Thomassen puts it, "Having no home, and therefore no real human and existential commitments, the trickster is not really interested in solving the liminal crisis: he simply pretends.” ${ }^{12}$ If one follows American politics the point becomes immediately obvious. Trump’s appeal was all about crisis - in the economy, in security, in immigration. It was the context in which Trump could thrive. It is no surprise that Trump's constant reiteration of crisis has not stopped after his election. The same political dynamic animated the Brexit campaign in Britain; it only made sense in the context of a crisis built on lies and emotional manipulation. Crisis animates rightwing political movements across Europe. Indeed, it had already become ubiquitous in public discourse before the rise of the New Authoritarians had fully crystallized. ${ }^{13}$

In the context of Egypt, one way to perpetuate liminal crisis was to foment strife, which 'Ukasha did with gusto, as he worked assiduously to set the public against the Revolution, revolutionaries against the Muslim Brotherhood, and Egypt ostensibly against the world, which was, in his narrative, rife with plotters aiming to destroy the country. But if 'Ukasha may be entirely legible within the terms of Trickster politics, then what can we say

\footnotetext{
12 Thomassen, 'Notes', pp. 695-696.

${ }^{13}$ Janet Roitman (2014) Anti-Crisis (Durham, NC: Duke University Press), pp. 16-17.
} 
about 'Abd al-Fattah al-Sisi? At first glance it might seem odd to speculate that an ironhanded dictator can be understood as a Trickster politician. But I think he should be.

Bjorn Thomassen and his colleague Rosario Forlenza published an article on Donald Trump as a Trickster politician, characterizing his appeal as "a toxic mix of fun and anger," and making him out to be a kind of "demonic clown. . . a figure of excess, especially of eating and drinking, and of sexual exploits, often depicted with an enormous phallus ... a breaker of taboos, a joker and prankster, the best of companions, but also a thief, a liar and an impostor...”. ${ }^{14}$ That fits Trump, and if one spends a few hours subjecting oneself to Taufiq 'Ukasha the image is immediately recognizable in him, too. But in politics the image of the Trickster as a "demonic clown” can be misleading. If Egypt is living the Age of the Trickster just as the United States and Europe are, then Sisi certainly is not that Trickster. His internationally circulated image is of a dour ruler admired by realpolitik Western politicians, presiding over the harsh suppression of Islamist insurgency and revolution, commanding the country to get serious and get back to work-all no-nonsense, and you laugh at your own risk.

But the role of a political trickster, if not the form, fits Sisi well enough: the pretend politician, the lack of existential commitments befitting his half-way position between a civilian government and a military that puts itself above the state; a purveyor of false charisma, and above all, an outsider who presents himself as "a solution to the crisis.” The fulcrum of a Trickster tale is that people are duped into feeling empowered for a while, but all too soon the feeling "dissolves into nothingness.” As political outsiders, Tricksters have enormous capacities for violence. The great European dictators of the twentieth century can be understood as Tricksters: Hitler, Mussolini and Stalin were brought to power by crisis, all of them telling their respective publics what they wanted to hear, and none of them

\footnotetext{
${ }^{14}$ Forlenza and Thomassen, ‘Decoding Donald Trump,’ pp.?? .
} 
sustainable except through violence. Sisi is small potatoes by comparison, but his regime is just as surely predicated on violence. As of September 2016, an expanding network of Egyptian prisons held around 60,000 political prisoners, out of a total prison population of $106,000^{15}$; suspected political opponents are subject to being “disappeared” without acknowledgement by the state ${ }^{16}$; extrajudicial assassination is sometimes practiced. ${ }^{17}$ Without such measures Sisi’s regime would be unsustainable.

Another sign of Sisi's Trickster politics is that he shows scant interest in politics. The parliament, once one was elected, was subservient to Sisi, but also featured no political party seeking to dispense patronage or discipline at the level of neighbourhoods, as Mubarak’s National Democratic Party did. To put it differently, Sisi’s regime, perhaps Sisi himself, has expended little effort in building hegemony_rule by consent of the governed, which can be horribly iniquitous, but is less openly violent. Coming into civilian rule as an outsider, Sisi continues to rule as an outsider, through violence paired with political spectacle.

The pattern of violence was established immediately with the massacre of around a thousand Muslim Brotherhood supporters on August 14, 2013. ${ }^{18}$ The pattern of political theatre emerged initially in support of a "War on terror," but then was expressed in other ways. A revealing instance of political theatre occurred in February 2014 when a news conference announced that an Egyptian army doctor had discovered a cure for AIDS and

\footnotetext{
${ }^{15}$ Arab Network for Human Rights Information (2016) 'There is Room for Everyone: Egypt’s Prisons before and after the January 25 Revolution.' Available online at: http://anhri.net/wp-content/uploads/2016/09/englishfinal-version-8-1.pdf, accessed on December 19, 2016.

${ }^{16}$ Egypt: Dozens Detained Secretly (2016), Human Rights Watch, July 20, 2011. Available online at https://www.hrw.org/news/2015/07/20/egypt-dozens-detained-secretly, accessed on August 13, 2016.

17 “Egypt: Police Account of Deadly Raid in Question” (2015) (31 July) Human Rights Watch: https://www.hrw.org/news/2015/07/31/egypt-police-account-deadly-raid-question accessed on 13 August, 2016.

${ }^{18}$ Human Rights Watch (2014) All According to Plan: The Rab'a Massacre and Mass Killings of Protestors in Egypt (New York: Human Rights Watch).
} 
Hepatitis C, along with a device that could diagnose viruses non-invasively. ${ }^{19}$ The doctor who took credit for the devices, Ibrahim 'Abd al-'Ati—presented to the public as General "Abd al-'Ati—famously said that his invention "took AIDS and fed it back to the patient like a piece of kufta.” Thereafter he was known as the kufta doctor and the cure as the kufta device.

Initial reports claimed that Sisi himself was present when 'Abd al-'Ati unveiled his phony inventions, but this was probably untrue. What was instructive, however, was that the regime doubled down on a bad bet. This could not have happened without Sisi’s assent. 'Abd al-'Ati swiftly was unmasked as a complete charlatan; his rank of "general” was ceremonial, bestowed on him because the head of the army’s engineering division "liked his ideas." ${ }^{20}$ Yet he was allowed for several months to appear in the media touting his device in full uniform. Moreover, the military announced that treatment by the inventions would begin on June 30, the anniversary of the Tamarrud demonstration that paved the way for Sisi's coup. The deadline passed with no unveiling of the treatment, and eventually the kufta doctor faded away. Sisi himself may have had little to do with the affair, and possibly was the one tricked by 'Abd al-'Ati. But in Trickster tales the Trickster is often precisely the person tricked, in the process of trying to trick others.

Although the kufta device only loosely was connected to Sisi, there was no ambiguity about the pattern it crystalized. On the one hand, the regime operates through violence, an ongoing state of emergency justified by threats from Islamists impossible to disentangle from the regime's own provocations, and harsh suppression of even the slightest criticism. On the other hand, the regime promises the sun, moon and stars to different constituencies. To court foreign backers Sisi offered neoliberal "reforms” such as the imposition of a value added tax,

\footnotetext{
${ }^{19}$ Al-Mu’tamar al-Suhufi lil-Quwwat al-Musallaha lil-‘Ilaj ‘an Jihaz al-Kashf ‘an al-Fayrusat” [English trans.?](2014). Availabel at https://www.youtube.com/watch?v=_2Y7t7tQ56E, accessed on August 13, 2016.

${ }^{20}$ Man Yakun al-Liwa’ ‘Abd al-‘Ati Mukhtara‘ Jihaz 'Ilaj’ al-Aydz’ [Eng. Translation?] (2014) Radio Sawa, 27 February, 2014. Available online at http://www.radiosawa.com/a/244588.html, accessed on August 13, 2016.
} 
the reduction of energy subsidies, downscaling of the civil service, and further gutting of Egypt's already weak labor laws. Not very much was done to carry out this agenda until, after 2016, the state indeed was compelled to implement such potentially explosive and indisputably painful (for the most vulnerable members of society) measures, but only because of Sisi's ability to continue stringing along his Gulf sponsors (Kuwait, Saudi Arabia and the United Arab Emirates), which had, up to the end of 2015, injected some $\$ 50$ billion into Egypt's central bank in order to keep the Egyptian pound from completely collapsing. ${ }^{21}$ Once the Gulf states grew disenchanted with Sisi, they cut him off. Without Gulf money Egypt was unable to prevent capital flight and, eventually, a sharp depreciation of the Egyptian pound, first on a black market and eventually officially.

Aside from Sisi's attempts to play his foreign backers, an increasingly restive public was treated to unending announcements of grand projects, virtually all of them re-packaged from the Mubarak era. They included a million-unit housing project-a scheme that had been announced five or six times previously; expensive reclamation of 4 million feddans of desert land for agriculture; numerous coastal and Canal-zone development schemes; and the “elimination” of informal housing. One of Sisi’s biggest megaprojects is a plan for a "new capital city" that would house seven million inhabitants and would be built in 7 years. ${ }^{22}$ It was announced with great fanfare during a “donor’s conference” in Sharm al-Shaykh. Foreign governments and corporations bandied about massive amounts of money that the public was told would be invested in Egypt. Few of the "promised" investment have materialized. Conferences of this sort famously produce "phantom donations”-discussion of projects, but no actual delivery of cash by the donors who are being wooed. In this case the

\footnotetext{
${ }^{21}$ Mohammed Ayesh (2016) The Case of the Disappearing Money - or How Egypt Descended into Economic Crisis, Middle East Eye, October 20, 2016. Available online at http://www.middleeasteye.net/columns/egypteconomics-pound-and-inevitability-collapse-368646136, accessed on December 19, 2016.

${ }^{22}$ Cairo Capital Partners (2015) A City Shaped by the Future (developers' website promoting a new capital city project). Available online at http://thecapitalcairo.com/about.html, accessed on August 14, 2016.
} 
“wooing” included promises from the Egyptian side to gut labor and investment laws further in order to entice foreign investment.

The kingpin of Sisi's megaprojects was the construction of a "new Suez Canal” on an expedited schedule, financed by selling bonds to the public. ${ }^{23}$ The project was actually a routine infrastructure upgrade comparable to many that had been made over the history of the Canal, and not particularly urgent by economic logic. It was nonetheless sold in 2014 to the public as an epic national achievement that would more than double Canal revenues within eight years. Numerous experts warned that the plan was based on unrealistic projections of global shipping volume. The project went ahead anyway. It was completed, on time but at high cost, in 2015. Subsequently Canal revenues have indeed dropped rather than risen. But the whole point was less economic benefit than political theatre.

The "New Canal” was a grand trick, and a successful one by most accounts. It was, however, also the high point of Sisi's grand gestures. The public became increasingly sceptical of his announcements of mega-projects, and started calling them fanakish — the plural of the word fankush, which comes from an old popular movie. ${ }^{24}$ A fankush is a fake object sold by a slick salesman to a naïve customer-a con job. The word first emerged in 2012 during the presidential campaign, when the Muslim Brotherhood’s “Nahda Program,” a political platform full of unrealistic developmental projects, was described as a fankush. "Morsi is selling the fankush," as an eloquent man put it in an interview that went viral. Today if one does a Google search for the term "fankush" the search must be delimited to 2012 in order to find it associated with Morsi. Otherwise, one finds only references to 'Abd al-Fattah al-Sisi’s latest fankush. In the protracted liminality of the revolutionary moment, the

\footnotetext{
${ }^{23}$ Timothy Kaldas (2015) Neither a Gift to the World nor a Money Pit Tahrir Institute for Middle East Policy, July 8, 2015. Available online at http://timep.org/commentary/neither-a-gift-to-the-world-nor-a-money-pit/, accessed on August 13, 2016.

${ }^{24}$ Nadir Galal (1984) Wahda bi-Wahda [Tit for Tat] (Cairo: Amal and Iman 'Abd al-Raziq). The film was based on a 1961 Rock Hudson film called Lover Come Back, which in turn was based on a pulp novel by Marvin Albert.
} 
"force of falsity" 25 of particularly a patently fake object was intense. In such circumstances fakes can serve as revelatory devices in an opaque political universe, ${ }^{26}$ endowing them with authority precisely when normative standards of authenticity were in doubt—rather like a Trickster.

Beyond the grand gesture of pretend politics, Trickster politics naturally connect to the sort of outlandish stories we call conspiracy theory, and also with the contemporary formation of so-called "Post-Truth Politics," which is a new label for an old phenomenon. There is a classic essay about the United States called 'The Paranoid Style in American Politics’ by the historian Richard Hofstadter, originally published in 1964, shortly after Barry Goldwater won the Republican nomination for the presidency. ${ }^{27}$ The Goldwater candidacy was the pinnacle of that particular episode in paranoid American politics; it had emerged initially during the anti-communist hysteria of the McCarthy era. The hallmark of the paranoid style was a sense of betrayal on the part of the right wing of the political spectrum. The idea was that "the old American virtues have already been eaten away by cosmopolitans and intellectuals"; it was not just that conspiracies sometimes happened, but that conspiracies were themselves the motive force in historical events. ${ }^{28}$ Hofstadter saw the 1950 s paranoias as being deeply imbued with racism and xenophobia. The Civil Rights movement was a communist plot; and communists were infiltrating the highest echelons of the American government. Hofstadter quotes Robert Welch, founder of the racist right-wing John Birch Society, making amazingly precise predictions of apocalypse: "Evidence is piling up on

\footnotetext{
${ }^{25}$ Umberto Eco (1999) Serendipities: Language and Lunacy (London: Phoenix).

${ }^{26}$ Nils Bubandt (2009) “From the Enemy’s Point of View: Violence, Empathy, and the Ethnography of Fakes” Cultural Anthropology 24 (3), p. 656.

${ }^{27}$ Richard Hofstadter (2008 [1964]), 'The Paranoid Style in American Politics,' in idem, The Paranoid Style in American Politics and Other Essays (New York: Random House), p. 29.
} 
many sides and from many sources that October 1952 is the fatal month when Stalin will attack.” ${ }^{29}$ Change a few details, and Welch morphs into Taufiq 'Ukasha predicting the fateful unfolding of a Masonic conspiracy on the $13^{\text {th }}$ day of the $13^{\text {th }}$ month of the year 2013 . Such discourse may indeed be paranoid, as Hofstadter says, but it is also the hallmark of a Trickster's pretend politics.

A stellar example of Egyptian paranoid politics was the prominence of the term “Fourth Generation Warfare.” The idea has an American genealogy. On one level it refers simply to warfare by means other than the military_-disinformation in media, funding civil society NGOs, even the simple spreading of rumours, all facilitated by a blurring of lines between war, politics, combatants and civilians. But more than that, Fourth Generation Warfare is a contemporary expression of Goldwater-style Paranoid Politics. As a term Fourth Generation Warfare is particularly associated with the self-styled military strategist and conservative polemicist William Lind, and dates at least from the late 1980 s. $^{30}$ A more recent summary of the concept can be found in Lind's $4^{\text {th }}$ Generation Warfare Handbook. ${ }^{31}$ Lind is a "paleoconservative" obsessed with the infiltration of American society by what he calls “cultural Marxists.” Paleoconservatism is a particularly reactionary form of American conservatism. Its proponents pointedly reject globalist forms of neoliberalism (or neoconservatism in American parlance), and "tend to centre upon the racial and ethnic identity of the United States, the historical presence of an innate social order; and the cultural

\footnotetext{
${ }^{29}$ Ibid, p. 30.

${ }^{30}$ William Lind, Keith Nightengale, John Schmitt, Joseph Sutton \& Gary Wilson (1989) 'The Changing Face of War: Into the Fourth Generation', Marine Corps Gazette, October, 22-26. Although Lind's initial “out-of-thebox" article was co-authored with military officers and published in the Marine Corps Gazette, Lind never served in the military or taught at a military academy. For a critical refutation of the Fourth Generation War concept from within the US Military see Antulio Echevarria II (2005) Fourth-Generation Warfare and Other Myths (Carlisle Barracks, PA: Strategic Studies Institute). The Strategic Studies Institute is part of the US Army War College, at which 'Abd al-Fattah al-Sisi was a student in 2006, but one should not assume that Sisi's promotion of Fourth Generation Warfare (as will be explained below) reflects institutionalized US military thinking.

${ }^{31}$ William Lind (2016) $4^{\text {th }}$ Generation Warfare Handbook (Kouvola, Finland: Castalia House).
} 
threats posed by the federal government and the welfare state.”32 Lind’s own formulation of paleoconservatism is best expressed by a novel titled Victoria, published in Finland under the pseudonym Thomas Hobbes. ${ }^{33}$ Victoria describes the breakup of the United States due to unsustainable "political correctness," culminating in the emergence of a Christian state in New England that enters into an alliance with the reconstituted Russian Czar against the Muslim world. With the election of Donald Trump Lind and paleoconservatism can perhaps no longer be described as marginal to American politics. ${ }^{34}$

The idea of Fourth Generation Warfare was introduced into Egyptian political discourse by 'Ukasha in 2011, and later repeated by numerous other television personalities and politicians. Once others started stealing his idea, 'Ukasha later one-upped himself and started talking about something called "Fifth Generation Warfare.” Take away the blanket accusation of cultural Marxism, and Lind’s big idea is essentially just an elaboration of "the well-established fact that lies, propaganda, and deceit are among the most powerful weapons in conflict and war.” ${ }^{35}$ States indeed have used many indirect means to weaken or confuse their opponents throughout history. But in the context of paranoid politics the label "Fourth Generation Warfare” is the perfect term for a phony expert or an authoritarian government

\footnotetext{
${ }^{32}$ Michael Foley (2007) American Credo: The Place of Ideas in American Politics (Oxford: Oxford University Press), p. 318.

33 Thomas Hobbes [William Lind] (2014) Victoria: A Novel of $4^{\text {th }}$ Generation War (Kouvola, Finland: Castalia House). The publisher, Castalia House, specializes in science fiction and political polemics, both authored by ultra-conservative (mostly self-consciously conservative Christian) writers. Lind's work is featured in both categories.

${ }^{34}$ Lind and Trump have met, to the alarm of liberal columnists, and to the amusement of Lind's ideological fellow travellers, who note the resonance of Lind's writing with Trump's campaign, but doubt whether Trump has actually imbibed Lind’s “philosophy.” See Jordan Bloom (2016) William Lind’s Way of War, The American Conservative, October 17, Available online at:

http://www.theamericanconservative.com/articles/william-linds-way-of-war/, accessed on January 8, 2017. For a liberal analysis of the Trump-Lind connection that is less coy about the ideological correspondences between the two see Paul Rosenberg (2016) Donald Trump’s Weaponized Platform: A Project Three Decades in the Making, Salon, July 16, 2016. Available online at:

http://www.salon.com/2016/07/16/donald_trumps_weaponized_platform_a_project_three_decades_in_the_mak ing/, accessed on January 8, 2017.

${ }^{35}$ Bubandt, 'From the Enemy’s Point', p. 560.
} 
looking for rationales to arrest opponents. Anything that one opposes politically can be seen as Fourth Generation Warfare, and everyone accused of it is fair game to be suppressed by paranoid governments.

Sisi also adopted the term openly. ${ }^{36}$ The Egyptian public was treated to a session in which he talked about "Fourth Generation Warfare” in early February 2015, during one of his many long and faux-intimate media appearances. He was shown sitting in his office, in a chair in front of his desk rather than seated behind it. This particular speech by Sisi was broadcast to counteract damaging leaks of recorded phone conversations in which he derisively talked about his Gulf patrons, characterizing their money as “rice.” He introduced his talk by invoking "Fourth Generation Warfare” in order to claim that the leaked conversation was fabricated by someone stealing his voice from the "thousands of hours" of recorded speech that had been broadcast.

I remind everyone who listens to me: Fourth Generation Warfare is a generation of the utmost importance that is being used in the entire region, and in Egypt. This generation is used in terrorism as an instrument; it's used in modern media; it's used in psychological warfare. It's a complete system that's used to bring an incredible result. Don’t ask about something that was said 'was it said or not?’ Ask 'Why was it said?' What was its purpose? ${ }^{37}$

The utility of the concept is that it is an endlessly elastic idea that can be used as a pretext for using violence against all political opponents. The fact that nations, movements,

\footnotetext{
${ }^{36}$ According to Bloom, American paleoconservatives are well aware of Sisi's preoccupation with Lind's concept (see n. 34 above).

${ }^{37}$ al-Sisi: Misr Tuwajih Akhtar Anwa‘ al-Hurub min al-Jil al-Rabi` (2015), February 22; Available online at https://www.youtube.com/watch?v=QnPgyXES93M, accessed on January 8, 2017.
} 
organizations and individuals do indeed have agendas makes conspiracy theorizing powerful in a liminal moment, when nobody is sure whom to believe or whom to follow.

We can summarize by noting that in "Trickster Politics" the figure of the Trickster is connected to liminality, and revolution can be understood as a liminal crisis in an unpredictable transition. I have instantiated a Trickster politician in Taufiq 'Ukasha, a counter-revolutionary propagandist, and possibly an operative of Egyptian military intelligence when it was run by 'Abd al-Fattah al-Sisi. Also, I’ve suggested that Sisi himself is a Trickster insofar as he comes into political office as an outsider, and rules as an outsider-capriciously by resorting to violence as a fundamental condition of governance, but also by means of substituting fantastic promises for political hegemony.

\section{Permanentized Liminality: The Age of the Trickster}

In conclusion, I want to take a speculative step further and ask whether the end of Egypt's revolution can be seen as a notable milestone in an inexorable global march into an "age of the Trickster.” There is no question that conceptualizing a dawning Age of the Trickster became an easier sell after Donald Trump won the presidency of the United States. With all due respect to 'Ukasha and Sisi, Trump is the Trickster politician par excellence. I think there is more Trump in Sisi than meets the eye, but ultimately, while we might argue about whether a given politician truly deserves to be described as a Trickster, the figure of the Trickster is universal. The point is to ask: What makes Tricksters audible in a given context? Trickster politicians are always in our midst, but people do not always listen to them. Now the whole world seems to be sitting up and paying attention to one Trickster after another.

What I want to leave you with is the observation that conspiracy theory, a coin that is convertible to paranoid politics and also to Trickster politics, is an indispensable part of the January 25 Revolution, specifically of the defeat of the Revolution's architects through the 
emergence of an unintended revolutionary outcome. We can see it in 'Ukasha, just as we find it in Sisi and Trump, and it always has been a part of European politics as well. The great tyrants of the $20^{\text {th }}$ century, Stalin and Hitler, bear more than a passing resemblance to the figure of the Trickster. ${ }^{38}$ Over the longer term there were always Tricksters operating within the interstices of the normal, often conjuring with paranoia that is thoroughly in step with our own times. Paranoia about Free Masons in the United States came from Europe, and Europe was, at one time, rife with lurid tales of the Illuminati plotting to take over the world in the wake of the French Revolution. One can almost hear an echo of tales of the Illuminati in Trump’s coded paranoia about Obama's relation to an imagined Muslim version of the Illuminati. “There’s something going on ...”39 His followers know precisely what he means. And alarmingly the last gasp of Trump's opponents trying to prevent his appointment to the presidency was to invoke a hidden Russian hand behind Trump—an unprovable allegation lying in a vast field of demonstrable lies and blatant provocations that would normally have amounted to instant disqualification for any other politician.

The point is that Trickster politics are common, but only effective in certain circumstances. Again, the question is not whether Trickster politics exists; it is rather when is it compelling? Why is Trump frighteningly audible to American voters? Why was Nigel Farage able to get British voters to buy into the fantasies of Brexit at a particular moment? Why was Taufiq 'Ukasha able to prepare the ground for the emergence of 'Abd al-Fattah alSisi?

\footnotetext{
38 Arpad Szakolczai (2009) Liminality and Experience: Structuring Transitory Situations and Transformative Events, International Political Anthropology 2 (1), p. 165.

39 Trump used the phrase often to insinuate conspiracy. See, for example, "People cannot believe that President Obama is acting the way he acts and can't even mention the words 'radical Islamic terrorism.' There's something going on. It's inconceivable.” See Trump Suggests 'There’s Something Going On' with Obama (2016) Washington Post Video Channel, June 13, 2016. Available online at https://www.washingtonpost.com/video/politics/trump-suggests-theres-something-going-on-withobama/2016/06/13/4b10e990-317f-11e6-ab9d-1da2b0f24f93_video.html, accessed on January 17, 2017.
} 
In the latter case-_Ukasha and Sisi-I have argued that revolution can be understood as a liminal crisis, and that in such a situation normal standards of leadership are suspended. Before the Revolution 'Ukasha was a loser—a minor figure in the National Democratic Party; a nobody in television journalism. During the Revolution he acquired a following. Ridicule by political sophisticates actually inflated 'Ukasha’s reputation. Like Trump, 'Ukasha intuitively understood that in a liminal crisis all publicity worked in his favour, even when he was mocked.

But if the emergence of 'Ukasha and then Sisi happened in the context of revolutionary crisis, then we must still ask why so many Trickster politicians are suddenly audible elsewhere, in societies that have not had revolutions. I think a number of factors increase the audibility of Tricksters. Some of them are of long historical duration, and others more recent. In the longue durée category, one might consider that modernity provides a structured production of instability, insofar as that it prioritizes endless progress through what some have called “creative destruction.” Indeed, some people see liminality as the core condition of modernity. ${ }^{40}$ In a similar vein Karl Marx famously argued that the point of modernity was that "all that is solid melts into air, all that is holy is profaned, and man is at last compelled to face with sober senses his real conditions of life, and his relations with his kind." ${ }^{41}$ This is a perfect recipe for liminality, and for this reason the figure of the specifically political Trickster in modern societies may have a resonance not found in the universal form of the Trickster. But Marx’s notion that modernity’s (and capitalism’s) “uninterrupted disturbance of all social conditions” would compel man “to face with sober senses his real conditions of life, and his relations with his kind” was shortsighted. The ideology and culture of modern societies is designed precisely to mitigate the unending liminality of modern

\footnotetext{
${ }^{40}$ Arpad Szakolczai (2000) Historical Reflexive Sociology (London: Routledge), pp. 207-219; and Thomassen, Liminality and the Modern.

${ }^{41}$ Karl Marx \& Friedrich Engels (1975 [1848]) Manifesto of the Communist Party, in Marx and Engels, The Marx-Engels Reader, Robert C. Tucker, ed. (New York: W.W. Norton), p. 476.
} 
capitalism conceived in this manner. Constructs of home and the Good Life are predisposed to stability. Even if we live in a world designed to fall constantly away in favour of endless change, we are still encouraged to believe that we can live within a safe normal. Brexiteers were told they could “take back control” by leaving the European Union; Donald Trump’s slogan was "Make American Great Again,” obviously to many of his followers coded language for “make America white again," but it also provides Trump supporters with plausible deniability: it means "make it safe; bring back what I consider normal, namely a secure job, a decent living, and a future for my children.” In Egypt Sisi’s supporters tried very hard to make him the new Nasser, not the Nasser of war and defeat, but the Nasser of progress and national pride.

Capitalism, grounded in the "all that is solid melts into air" ethos that Marx formulated, was about unending revolutionizing of the means of production, which is another way of expressing permanent liminality. But capitalism also sutured itself ideologically to all that was wholesome, secure and traditional—-home and hearth; solid bourgeois values; even religion. This was hegemony in the most technical sense—a case in which "particularity assumes the representation of an (impossible) universality entirely incommensurable with it," as Ernesto Laclau put it; ${ }^{42}$ the solidity of bourgeois family values, often buttressed by religion, assuming a universality with a capitalism entirely incommensurable with such values because it is predicated on the permanent revolutionizing of the means of production. Nonetheless, this hegemony has functioned in many places over long stretches for the past couple of centuries. Many people understood social conditions, which could have been experienced as permanent liminality, instead as solid, conventional, and conservative. But now it doesn't seem to work so well. Why?

\footnotetext{
42 Ernesto Laclau (2000) 'Power and Social Communication,' in Ethical Perspectives 7 (2-3), p. 140.
} 
One reason is that capitalism has evolved into neoliberal ideology at odds with the hegemony of bourgeois solidity. Neoliberalism, particularly as it has been instituted since the 1970s, differs from classical liberalism in that it reduces freedom to the economic sphere. This is how political theorist Wendy Brown describes it:

[Neoliberalism] transmogrifies every human domain and endeavor, along with humans themselves, according to a specific image of the economic. All conduct is economic conduct; all spheres of existence are framed and measured by economic terms and metrics, even when those spheres are not directly monetized. In neoliberal reason and in domains governed by it, we are only and everywhere homo oeconomicus. ${ }^{43}$

"Homo oeconomicus" has to be governed intensely in order to be productive. This type of governance strips away older forms of capitalist hegemony, leaving people in liminality.

And so perhaps we can see the difference between liminality in the form of the ritual process, and the structured liminality of precarious neoliberalism. Liminal crisis conceived in the terms of the ritual process writ large is a moment of political fluidity characteristic of all revolutionary events, perfect for the emergence of a Trickster, but also genuinely open to contingency and hence potentially grounds for the emergence of other political formations. Permanentized instability is a synthetic form of liminality that governments endeavor to keep within manageable limits. The degree to which it is deliberately structured is debatable, but it is worth noting that instability is not at all out of place in a neoliberal order. "Crisis capitalism"- the opportunistic exploiting of capitalism to further the cause of refashioning human beings as homo oeconomicus, is one way of expressing that kind of instability. Contemporary capitalism welcomes crisis because it affords opportunities to impose policies

\footnotetext{
${ }^{43}$ Wendy Brown (2015) Undoing the Demos: Neoliberalism's Stealth Revolution (New York, NY: Zone Books), pp. 9-10.
} 
that voters in a democratic system would never endorse. ${ }^{44}$ Milton Friedman, one of the primary ideological architects of neoliberalism, famously stated that crisis breaks "the tyranny of the status quo — in private and especially governmental arrangements," 45 and that the function of those committed to "freedom" as he understood it, was "to develop alternatives to existing policies, to keep them alive and available until the politically impossible becomes politically inevitable.” 46 That statement has been often remembered by academics, and elaborated. ${ }^{47}$ Thomassen also suggests that liminality is built into the contemporary economic system in myriad ways, ranging from the permanentization of the carnivalesque instantiated in popular culture to the breaching of the most psychologically permanent refuge, "the home," in the interest of converting it into an economic asset that can in effect become a chip in the great game of "casino capitalism.” 48 He does not mention “crisis capitalism” specifically, but it is consistent with his general logic of liminality coming to "occupy a more and more central place within the space of modernity, a process which is currently accelerating to the point of absurdity." 49

Roitman and others also have noted that while the status of both "crisis" and "normality" as objects of inquiry need not be taken for granted, narrations of crisis have become particularly salient in recent years. ${ }^{50}$ Reinhart Koselleck, in his crisis-centred conception of history, expresses skepticism at the "imprecision" of contemporary crisis narrations, complaining that a concept that "once had the power to pose unavoidable, harsh

\footnotetext{
${ }^{44}$ Naomi Klein (2008) The Shock Doctrine: The Rise of Disaster Capitalism (London: Penguin).

${ }^{45}$ Milton Friedman (2002) Capitalism and Freedom; Fortieth Anniversary Edition (Chicago: University of Chicago Press), pp. xii-xiv.

${ }^{46}$ Ibid, xiv.

${ }^{47}$ Adam Hanieh (2013) Lineages of Revolt: Issues of Contemporary Capitalism in the Middle East (Chicago, IL: Haymarket Books), pp. 48-52.

48 Thomassen, Liminality and the Modern, pp. 218-225.

${ }^{49}$ Ibid, p. 11.

${ }^{50}$ Roitman, Anti-Crisis, p. 3.
} 
and non-negotiable alternatives, has been transformed to fit the uncertainties of whatever might be favored at a given moment." ${ }^{51}$ But it is exactly the compulsion of taking "harsh and non-negotiable" decisions in the political-economic sphere that drives "crisis capitalism"the formulation of crisis to which I allude here. Both capitalism and Marxism historically sought to convert all forms of economic indeterminism into calculable risks. ${ }^{52}$ Neoliberalism, by contrast, puts greater emphasis on indeterminacy than on risk, because "creative destruction”53 provides much greater opportunity for re-engineering society in order to protect capital accumulation by elites than state-centric risk management.

The result is what political theorist Isabel Lorey describes as "government of the precarious" in which "precarious living and working conditions are currently normalized at a structural level and thus have become a fundamental governmental instrument." ${ }^{54}$ A neoliberal system that reneges on general welfare and instead prioritizes its resources more narrowly on safeguarding the security of an elite was a root cause of Egypt's revolution. The point of a "government of the precarious" is to balance "a maximum of precarization, which probably cannot be exactly calculated, with a minimum of safeguarding to ensure that the minimum is secured at this threshold."55

In other words, certain constituent parts of society are kept below the threshold of revolution, and above the threshold of absolute poverty, thus potentially prone to buying into a system requiring belief in the capacity for individual self-improvement. But the space

\footnotetext{
${ }^{51}$ Reinhart Koselleck (2006) ‘Crisis’, Tr. Michaela Richter, in: Journal of the History of Ideas 67(2), p. 399.

${ }^{52}$ Roitman, Anti-Crisis, pp. 72-73.

${ }^{53}$ David Harvey (2005) A Brief History of Neoliberalism (Oxford: Oxford University Press), p. 12.

${ }^{54}$ Isabell Lorey (2015) State of Insecurity: Government of the Precarious (London: Verso), p. 63.

${ }^{55}$ Ibid, p. 65.
} 
between these thresholds — a space of synthetic liminality—also may be precisely the social position at which a Trickster politician is maximally audible: Taufiq 'Ukasha spinning bizarre conspiracy theories; Sisi pitching ever grander megaprojects; British voters captivated by Boris Johnson’s unfulfillable Brexit promises; Donald Trump whipping crowds into a frenzy with promises to “make America great again” by building walls to keep Mexicans out and forbidding Muslims from coming in. Maintaining the thresholds of this structured precarity is, ironically, a quintessentially precarious task, which is to say, the perfect job for a Trickster, someone who is "at one and the same time creator and destroyer, giver and negator, he who dupes others and who is always duped himself.”56

In the end, the question of how revolutions end, on one hand, must account for the fact that the constellation of self-consciously pro-democracy political forces we conventionally understand as The January $25^{\mathrm{t}}$ Revolution certainly was defeated by 'Abd alFattah al-Sisi, and did not simply "fail” on its own accord. But to call Sisi to face a counterrevolutionary project implicitly interprets him as a straightforward restoration of the old regime, and precludes understanding him as a revolutionary outcome-one that "shifts control over a state to a new set of rulers.”57 Conventionally this was (and for some still is) the gold standard for determining whether a given uprising should be considered a true social revolution. Revolution understood as a liminal crisis facilitates a more flexible view of what counts as a revolutionary outcome. What happened in Egypt is far from the first instance of a revolution that resulted in an unexpected outcome. On the other hand, a different form of liminality—permanentized precarity structured by an ideological project of long durationcreates both a crisis that demands rebellion and an efficient incubator of authoritarian politics. Perhaps not only authoritarian politics, as a roster of progressive figures and

\footnotetext{
${ }^{56}$ Radin, p. xxii.

${ }^{57}$ Charles Tilly (2006) Regimes and Repertoires (Chicago: University of Chicago Press), p. 160.
} 
movements emerging in parallel to the burgeoning political Right over the past decade or so in Europe and elsewhere suggests. But for every Podemos or Bernie Sanders who comes tantalizingly close to achieving political relevance, there seems to be a Trump or a Sisi who actually seizes power.

If the January 25 Revolution was structured by permanentized precarity, it ended in the triumph of Trickster politics. And yet it must be said that trickster tales often end in disaster. Can we imagine, for example, a Trump presidency coming to disaster? More to the point for present purposes, Western governments that interpret Sisi as an unfortunate but necessary bulwark against the chaos of undisciplined freedom are grievously misunderstanding the structured precarity at the heart of the regime’s capacity to govern. Perhaps such precarity is so close to their own governing strategies that they no longer can tell whether they’ve been Tricked. 


\section{References}

Arab Network for Human Rights Information (2016) 'There is Room for Everyone: Egypt's Prisons before and after the January $25^{\text {th }}$ Revolution.' Available online at http://anhri.net/wp-content/uploads/2016/09/english-final-version-8-1.pdf. Accessed on December 19, 2016.

Armbrust, W. (2013) 'The Trickster in the January 25 Revolution. In: Comparative Studies in Society and History, 55(4), pp. 834-864.

Armbrust, W. (2015) Hawi al-Thaura al-Misriyya: Dirasa Antrubulujiyya li-Zahirat Taufiq 'Ukasha [English trans. in brackets] (Riyad: Kingdom of Saudi Arabia: Markaz Nama').

Asbab Isqat ‘Adawiyyat Taufiq 'Ukasha min al-Barliman (2016) Al-Barlimani, March 2, 2016. Available online at http://tinyurl.com/jlbwqz8, accessed on December 19, 2016. No author, correct?

Ayesh, M. (2016) 'The Case of the Disappearing Money - or How Egypt Descended into Economic Crisis.’ In: Middle East Eye, October 20. Available online at: http://www.middleeasteye.net/columns/egypt-economics-pound-and-inevitabilitycollapse-368646136. Accessed on December 19, 2016.

Barakat, H. (2015) Hisham Barakat Yaktub ‘an Taufiq ‘Ukasha, The Glenn Beck [of] Masr [Eng. Trans.] Al-Mugaz, December 9. Available online at: http://www.elmogaz.com/node/244630. Accessed on December 1, 2016.

Bell, C. (2009) Ritual Theory, Ritual Practice. Oxford, UK: University of Oxford Press. 
Bloom, J. (2016) 'William Lind’s Way of War. In: The American Conservative, October 17. Available online at: http:/www.theamericanconservative.com/articles/william-lindsway-of-war/. Accessed on January 8, 2017.

Brown, W. (2015) Undoing the Demos: Neoliberalism's Stealth Revolution. New York: Zone Books.

Bubandt, N. (2009) 'From the Enemy’s Point of View: Violence, Empathy, and the Ethnography of Fakes. In: Cultural Anthropology, 24(3), pp. 553-588.

Cairo Capital Partners (2015) ‘A City Shaped by the Future’ [developers’ website promoting a new capital city project]. Available online at: http://thecapitalcairo.com/about.html. Accessed on August 14, 2016.

Carr, S. (2011) ‘A Firsthand Account: Marching from Shubra to Deaths at Maspero.’ In: Egypt Independent, October 10. Available online at: http://www.egyptindependent.com/news/firsthand-account-marching-shubra-deathsmaspero, accessed on January 24, 2016.

Echevarria II, A. (2005) Fourth-Generation Warfare and Other Myths. Carlisle Barracks, PA: Strategic Studies Institute.

Eco, U. (1999) Serendipities: Language and Lunacy. London: Phoenix.

Al-Fidyu al-Kamil li-Intihakat al-Gaysh fi Maglis al-Wuzara’ [Eng. Trans.] (2011). Available online at: https://www.youtube.com/watch?v=KjHO3CjBsgs. Accessed on December 21, 2016.

Foley, M. (2007) American Credo: The Place of Ideas in American Politics. Oxford, UK: Oxford University Press.

Forlenza, R. \& Thomassen, B. (2016) 'Decoding Donald Trump: The Triumph of Trickster Politics', Public Seminar, April 28. Available online at: 
http://www.publicseminar.org/2016/04/decoding-donald-trump-the-triumph-oftrickster-politics/\#.V4uVB5MrLys. Accessed on July 17, 2016.

Friedman, M. (2002) Capitalism and Freedom; Fortieth Anniversary Edition. Chicago: University of Chicago Press.

Galal, N. (1984) Wahda bi-Wahda [Tit for Tat]. Cairo: Amal and Iman 'Abd al-Raziq. van Gennep, A. (2004 [1909]) The Rites of Passage, Vizedom, M. \& Caffee, G., trans. London: Routledge.

Al-Halqa al-Kamila li-Birnamig ‘Masr al-Yaum’ [Eng. Trans.] (2015). Available online at: https://www.youtube.com/watch?v=3f_RgE3cU44. Accessed on December 19, 2016.

Hanieh, A. (2013) Lineages of Revolt: Issues of Contemporary Capitalism in the Middle East. Chicago, IL: Haymarket Books.

Harvey, D. (2005) A Brief History of Neoliberalism. Oxford: Oxford University Press.

Hobbes, T. [William Lind] (2014) Victoria: A Novel of $4^{\text {th }}$ Generation War. Kouvola, Finland: Castalia House.

Hofstadter, R. (2008 [1964]) The Paranoid Style in American Politics and Other Essays. New York: Random House.

Human Rights Watch (2014) All According to Plan: The Rab`a Massacre and Mass Killings of Protestors in Egypt. New York: Human Rights Watch.

Human Rights Watch (2015a) 'Egypt: Dozens Detained Secretly.’ Available online at: https://www.hrw.org/news/2015/07/20/egypt-dozens-detained-secretly. Accessed on August 13, 2016.

Human Rights Watch (2015b) “Egypt: Police Account of Deadly Raid in Question.” Available online at: https://www.hrw.org/news/2015/07/31/egypt-police-accountdeadly-raid-question. Accessed on 13 August, 2016. 
El Husseini, M. (2011) The 'Maspero Crime’: Accounts against the Counter-Revolution’s Power, Media, and Religion, Jadaliyya, October 31, 2011. Available online at http://www.jadaliyya.com/pages/index/3022/the-maspero-crime_accounts-against-thecounter-rev. Accessed on January 24, 2016.

‘Isam, R. (2011) ‘Ughniyya Ya ‘Uksha Ihda’ li-Taufiq ‘Ukasha min Midan al-Tahrir’ [Eng. Trans.]. Available online at: https://www.youtube.com/watch?v=4aIFMviAUuc. Accessed on August 2, 2016.

Kaldas, T. (2015) 'Neither a Gift to the World or a Money Pit.’ In: Tahrir Institute for Middle East Policy, July 8. Available online at: http://timep.org/commentary/neither-a-giftto-the-world-nor-a-money-pit/. Accessed on August 13, 2016.

Klein, N. (2008) The Shock Doctrine: The Rise of Disaster Capitalism. London: Penguin.

Koselleck, R. (2006) 'Crisis,’ Richter, M., trans. In: Journal of the History of Ideas 67(2), pp. $357-400$.

Laclau, E. (2000) ‘Power and Social Communication.’ In: Ethical Perspectives 7(2-3), pp. $139-145$.

Lind, W. (2016) $4^{\text {th }}$ Generation Warfare Handbook. Kouvola, Finland: Castalia House.

Lind, W., Nightengale, W., Schmitt, J., Sutton, J. and Wilson, G. (1989) 'The Changing Face of War: Into the Fourth Generation. In: Marine Corps Gazette, October 22-26.

Lorey, I. (2015) State of Insecurity: Government of the Precarious. London: Verso.

Marx, K. \& Engels, F. (1975 [1848]) ‘Manifesto of the Communist Party.’ In: Tucker, R. C. (ed.), The Marx-Engels Reader, pp. 469-500. New York: W.W. Norton. 
Radio Sawa (2014) ‘Man Yakun al-Liwa’ ‘Abd al-‘Ati Mukhtara‘ Jihaz 'Ilaj’ al-Aydz’, 27

February, 2014. Available online at: http://www.radiosawa.com/a/244588.html. Accessed on August 13, 2016.

Radin, P. (1956) The Trickster: A Study in American Indian Mythology, with commentary by Karl Kerényi and Carl G. Jung. New York: Philosophical Library.

Roitman, J. (2014) Anti-Crisis. Durham, NC: Duke University Press.

Rommel, C. (2015) 'Revolution, Play and Feeling: Assembling Emotionality, National Subjectivity and Football in Cairo, 1990-2013’, PhD Thesis, University of London, School of Oriental and African Studies.

Rosenberg, P. (2016) ‘Donald Trump’s Weaponized Platform: A Project Three Decades in the Making.' In: Salon, July 16. Available online at: http://www.salon.com/2016/07/16/donald_trumps_weaponized_platform_a_project_t hree_decades_in_the_making/. Accessed on January 8, 2017.

Ryzova, L. (2011) ‘Teargas, Hairgel and Tramadol: The Battle of Mohamed Mahmud Street,' in Jadaliyya, November 28. Available online at: http://www.jadaliyya.com/pages/index/3312/the-battle-of-muhammad-mahmudstreet_teargas-hair-. Accessed on August 12, 2016.

al-Sisi, A. (2015) 'Misr Tuwajih Akhtar Anwa' al-Hurub min al-Jil al-Rabi' [English trans.], Feb. 22. Available online at: https://www.youtube.com/watch?v=QnPgyXES93M. Accessed on January 8, 2017.

Suez Canal Authority (2015) ‘New Suez Canal.’ Available online at: http://www.suezcanal.gov.eg/sc.aspx?show=69. Accessed on August 13, 2016.

Szakolczai, A. (2000) Historical Reflexive Sociology. London: Routledge. 
Szakolczai, A. (2009) 'Liminality and Experience: Structuring Transitory Situations and Transformative Events.'In: International Political Anthropology 2(1), pp. 141-172.

Taufiq ‘Ukasha Yahdhar min 13/13/13 (2011). Available online at:

https://www.youtube.com/watch?v=8YfVtNxMzT0. Accessed on 7 January, 2017.

Thomassen, B. (2012) ‘Notes Toward an Anthropology of Political Revolutions.’ In:

Comparative Studies in Society and History, 54(3), pp. 679-706.

(2014) Liminality and the Modern: Living through the In-between

(London: Routledge).

Tilly, C. (2006) Regimes and Repertoires. Chicago: University of Chicago Press.

Turner, V. (1977) The Ritual Process: Structure and Anti-Structure. Cornell: Cornell University Press.

‘Ukasha fi Aqwa Ta‘liq ‘ala Kitab Hawi al-Thaura [Eng. Trans.??] (2015). Available online at https://www.youtube.com/watch?v=Ks14_d9Lb8E. Accessed on 7 January, 2017.

‘Ukasha Yatanaba’u bi-Tai‘yin ‘Abd al-Fattah al-Sisi Ragil al-Ikhwan fi al-Gaysh [Eng. Trans.?] (2012). Available online at:

https://www.youtube.com/watch?v=CYrJRWveQTw, accessed on August 2, 2016.

Washington Post (2016) 'Trump Suggests There’s Something Going On with Obama.'

Washington Post Video Channel, June 13, 2016. Available online at

https://www.washingtonpost.com/video/politics/trump-suggests-theres-something-

going-on-with-obama/2016/06/13/4b10e990-317f-11e6-ab9d-

1da2b0f24f93_video.html. Accessed on January 17, 2017.

Youtube (2014) “Al-Mu’tamar al-Suhufi lil-Quwwat al-Musallaha lil-‘Ilaj ‘an Jihaz al-Kashf 'an al-Fayrusat” [Eng. Trans.]. Available at:

https://www.youtube.com/watch?v=_2Y7t7tQ56E. Accessed on August 13, 2016. 